EMPOWER : Jurnal Pengembangan Masyarakat Islam

Vol. 5, No.1, Juni 2020, hlm. 64-82

e-ISSN : 2580-0973, p-ISSN : 2580-085X

Tersedia Online di : http://syekhnurjati.ac.id/jurnal/index.php/empower

Email : empowerjurnal@gmail.com

\title{
Peran Masyarakat Dalam Proses Diversi Tindak Pidana Anak Sebagai Upaya Mewujudkan Keadilan Restoratif
}

\author{
Imam Ahmad Ghazali \\ (Balai Pemasyarakatan Kelas 1 Cirebon) \\ E-mail: imamghozali857@yahoo.com
}

\section{Article History}

Submitted: 24.04.2020; Revised: 22.06.2020; Accepted: 22.06.2020;

\begin{abstract}
The Law of the Republic of Indonesia Number 11 of 2012 Concering Children's Criminal Court System, effective from July 31, 2014. This law can solve various issues of the children facing Law based on restorative justice principles. In the regulation it is discussed about diversion concept involving several parties and one of them is the community. This research aims to illustrate how community involvement and its operations in the implementation of the diversion as an attempt to create a restorative justice. The research method used is the juridical approach of empiris with qualitative analysis data. The research object is the completion of a child's criminal offence which is resolved through the diversion process. The results showed that the involvement of the society is not optimal in the process of diversion because it is influenced by several factors. That is a factor understanding restorative justice approach from the apparatus and society, factors of infrastructure and cultural law.
\end{abstract}

Keywords: Role of Diverse Communities and Restorative Justice

\begin{abstract}
Abstrak
Undang-Undang Republik Indonesia Nomor 11 Tahun 2012 Tentang Sistem Peradilan Pidana Anak yang lahir pada tahun 2012, diberlaku sejak 31 Juli 2014 menggantikan UU Nomor 3 Tahun 1997 tentang Pengadilan Anak. Undang-undang ini digadang-gadang dapat menyelesaikan berbagai permasalahan Anak yang Berhadapan dengan Hukum $(\mathrm{ABH})$ yang belum bisa
\end{abstract}


dituntaskan oleh pearturan sebelumnya dengan mengedepankan azas Keadilan Restpratif. Di dalam regulasi tersebut dibahas khusus tentang Diversi yang melibatkan beberapa pihak dan salah satunya adalah masyarakat. Penelitian ini bertujuan untuk menggambarkan bagaimana keterlibatan masyarakat dan kendalanya dalam pelaksanaan Diversi baik dari proses upaya Diversi hingga pelaksanaan hasil kesepakatannya sebagai upaya mewujudkan Keadilan Restorative. Metoda Penelitian yang digunakan adalah pendekatan yuridis Empiris dengan data analisa Kualitatif. Sedangkan objek penelitian adalah Penyelesaian perkara tindak pidana anak yang yang diselesaikan melalui proses Diversi. Hasil penelitian menunjukan bahwa keterlibatan masyakat yang belum optimal baik dalam proses upaya Diversi maupun pelaksanaan hasil kesepakatannya karena dipengaruhi oleh beberapa faktor antara lain Faktor Pemahaman tentang Sistem Peradilan Pidana Anak dengan pendekatan Keadilan Restpratif baik pada Aparat maupun masyarakat, Sarana Prasarana dan Budaya hukum.

Kata kunci: Peran Masyarakat Diversi dan Keadilan Restoratif

\section{PENDAHULUAN}

Akhir tahun 2019 hingga memasuki tahun 2020, tindak pidana yang dilakukan oleh anak masih cukup tinggi, mayoritas adalah tindak pidana kekerasan fisik, tawuran antar kelompok remaja di Kota Cirebon dan sekitarnya. Faktor penyebab hanya hal sepele, saling ejek atau dengan sengaja mencari lawan di media sosial. Tujuannya untuk melakukan tawuran di tempat tertentu sesuai kesepakatan yang mereka buat. Aksi tawuran tersebut biasa disebut konten, bancakan atau siaran langsung.

Kelompok remaja melakukan tawuran hanya untuk exixtensi kelompok, menunjukkan kepada kelompok lain bahwa kelompoknya paling kuat, hebat, dan disegani. Hal ini diungkapkan tokoh pemuda Cirebon, Jaka Permana yang merupakan panglima XTC Kota Cirebon. Meereka hanya meniru dan ingin gaya"an tanpa memikirkan dampak negatifnya, kebanyakan kelompok kecil adopsi dari 65amper65 karena mulai asal trenya disana, Cirebon jadi terbawa dan ikut"an,klo jaman dulu 
mungkin perang kampung dikarenakan perkembangan jaman dan 66amper semua anak memakai android, kelompok ini gabungan antar kampung, bedanya aksi mreka dijalanan meyerupai geng motor, mungkin bisa juga ada dalang dibalik semuanya, agar geng motor yg sudah eling/ hijrah ini kembali brutal," yang Jack pantau dari sebagian mreka juga ada org" mantan geng yg tidak mau baik. Penyebabnya tawuran kurangnya perhatian dan pembinaan, pendampingan dilingkungan keluarga /lingkungan pergaulan dimana setiap anak yang saya tahu penyebab tawuran tersebut adalah saling ejek dan adu ketangkasan yg dimana tiap daerah memiliki basis atau nama keren Camp, kebanyakan dari mereka anak pelajar yg ingin menonjolkan jati dirinya, dan dari pelaku tawuran mereka bisa saling kontak dan janjian tempat pula ${ }^{1}$

Telah banyak jatuh korban akibat dari tindak pidana ini. Kerugian tidak hanya materi, terkadang korban luka bahkan meninggal dunia. Kenyamanan dan keamanan kota Cirebon terganggu, masyarakat pun menjadi resah. Bahkan kasus yang terakhir, tawuran di Daerah Katiasa Kota Cirebon pada awal Januari 2020 berakibat dua korban meninggal dunia.

Data yang diperoleh dari Bapas Kelas I Cirebon pada tahun 2019 jumlah ABH 134 anak, 51 diantaranya perkara tindak kekerasan, 35 perkara pencurian, 10 perkara perampokan. Berdasarkan wilayah kerja, Kota Cirebon tertinggi dengan 35 kasus selanjutnya Kabupaten Indramayu dengan 30 kasus, Kabupaten Cirebon 24 kasus, Kabupaten Kuningan 11 kasus, dan Kabupaten Majalengka 8 kasus Anak². Sementara itu pada pada tahun 2019 di wilayah hukum Kota Cirebon sebanyak 10 perkara diselesaikan melalui proses diversi. Sampai dengan awal Bulan Mei 2020 berdasarkan data dari Fain, Pekerja Sosial Profesional Dinas Sosial

\footnotetext{
${ }_{1}$ Wawancara dengan Jaka Permana Panglima XTC Kota Cirebon, pada tanggal 10 April 2020

2 Sumber Data Balai Pemasyarakatan (Bapas) Pas Kelas 1 Cirebon (Cirebon, 2019).
} 
Pemberdayaan Perempuan dan Perlindungan Anak Kota Cirebon dapat dilihat pada table berikut:

Tabel 1. Data Diversi Anak Berhadapan Dengan Hukum (ABH) Yang
Ditangani Sakti Peksos Kota Cirebon Periode 2020

$\begin{array}{lll} & \text { Status: } \\ \text { No Usia } & \text { Pelaku }\end{array}$

KASUS ALAMAT

KETERANGAN

L $\quad$ P

\begin{tabular}{|c|c|c|c|c|c|}
\hline 1 & $14 \mathrm{Th}$ & $\mathrm{v}$ & Laka Lantas & Kab. Cirebon & Diversi Polres Ciko \\
\hline 2 & $17 \mathrm{Th}$ & $\mathrm{v}$ & Pengeroyokan & Kab. Cirebon & Diversi Polres Ciko \\
\hline 3 & $17 \mathrm{Th}$ & $\mathrm{v}$ & Pengeroyokan & Kab. Cirebon & Diversi Polres Ciko \\
\hline 4 & $16 \mathrm{Th}$ & $\mathrm{v}$ & Pengeroyokan & Kab. Cirebon & Diversi Polres Ciko \\
\hline 5 & $16 \mathrm{Th}$ & $\mathrm{v}$ & Pengeroyokan & Kab. Cirebon & Diversi Polres Ciko \\
\hline 6 & $15 \mathrm{Th}$ & $\mathrm{v}$ & Penganiayaan & Kab. Indramayu & Diversi Polres Ciko \\
\hline 7 & $17 \mathrm{Th}$ & $\mathrm{v}$ & Penganiayaan & Kota Jakarta Selatan & Diversi Polres Ciko \\
\hline 8 & $17 \mathrm{Th}$ & $\mathrm{v}$ & Penganiayaan & Kab. Indramayu & Diversi Polres Ciko \\
\hline 9 & $12 \mathrm{Th}$ & $\mathrm{v}$ & Penganiayaan & Kab. Karawang & Diversi Polres Ciko \\
\hline 10 & $17 \mathrm{Th}$ & $\mathrm{v}$ & Penganiayaan & Jakarta timur & Diversi Polres Ciko \\
\hline 11 & $17 \mathrm{Th}$ & $\mathrm{v}$ & Penganiayaan & Kab. Cirebon & Diversi Polres Ciko \\
\hline 12 & $17 \mathrm{Th}$ & $\mathrm{v}$ & Penganiayaan & Kab. Kuningan & Diversi Polres Ciko \\
\hline 13 & $13 \mathrm{Th}$ & & Penganiayaan & Kota Cirebon & Diversi Polres Ciko \\
\hline \multirow[t]{2}{*}{14} & $14 \mathrm{Th}$ & $\mathrm{v}$ & Penganiayaan & Tanggerang & Diversi Polres Ciko \\
\hline & & & & Selatan & \\
\hline 15 & $12 \mathrm{Th}$ & $\mathrm{v}$ & Tawuran & Kota Cirebon & Diversi Polres Ciko \\
\hline 16 & $14 \mathrm{Th}$ & $\mathrm{v}$ & Tawuran & Kota Cirebon & Diversi Polres Ciko \\
\hline 17 & $13 \mathrm{Th}$ & $\mathrm{v}$ & Tawuran & Kota Cirebon & Diversi Polres Ciko \\
\hline 18 & $15 \mathrm{Th}$ & $\mathrm{v}$ & Tawuran & Kota Cirebon & Diversi Polres Ciko \\
\hline 19 & $14 \mathrm{Th}$ & $\mathrm{v}$ & Tawuran & Kota Cirebon & Diversi Polres Ciko \\
\hline 20 & $13 \mathrm{Th}$ & $\mathrm{v}$ & Tawuran & Kab. Cirebon & Diversi Polres Ciko \\
\hline 21 & $13 \mathrm{Th}$ & $\mathrm{v}$ & Tawuran & Kota Cirebon & Diversi Polres Ciko \\
\hline
\end{tabular}




\begin{tabular}{cccccc}
22 & $14 \mathrm{Th}$ & v & Tawuran & Kota Cirebon & Diversi Polres Ciko \\
23 & $17 \mathrm{th}$ & v & Tawuran & Kota Cirebon & Diversi Polres Ciko \\
24 & $15 \mathrm{Th}$ & v & Tawuran & Kota Cirebon & Diversi Polres Ciko \\
25 & $17 \mathrm{Th}$ & v & Tawuran & Kota Cirebon & Diversi Polres Ciko \\
26 & $14 \mathrm{Th}$ & v & Tawuran & Kota Cirebon & Diversi Polres Ciko \\
27 & $5 \mathrm{Th}$ & v & Tawuran & Kota Cirebon & Diversi Polres Ciko \\
\hline
\end{tabular}

Dari table tersebut terlihat bahwa angka diversi menunjukkan peningkatan yang signifikan. Upaya hukum yang dilakukan adalah memproses Anak yang Berhadapan dengan Hukum (ABH), melalui persidangan maupun penyelesian melalui proses diversi. Namun pada kenyataannya, kejadian tindak pidana anak khususnya kekerasan fisik terus berulang bahkan dengan pelaku yang sama (mengulang), hal ini mengindikasikan proses diversi yang melibatkan peran masyarakat dan pihak terkait belum dapat mewujudkan keadilan restoratif.

Diversi adalah pengalihan penyelesaian perkara Anak dari proses peradilan pidana ke proses di luar peradilan pidana ${ }^{3}$. Sedangkan yang dimaksud dengan Keadilan Restoratif adalah penyelesaian perkara tindak pidana dengan melibatkan pelaku, korban, keluarga pelaku/korban, dan pihak lain yang terkait untuk bersama-sama mencari penyelesaian yang adil dengan menekankan pemulihan kembali pada keadaan semula, dan bukan pembalasan ${ }^{4}$.

Restorative Justice mengandung pengertian yaitu suatu pemulihan hubungan dan penebusan kesalahan yang ingin dilakukan oleh pelaku tindak pidana (keluarganya) terhadap korban tindak pidana tersebut (keluarganya) (upaya perdamaian) di luar pengadilan dengan maksud dan tujuan agar permasalahan hukum yang timbul akibat terjadinya perbuatan

\footnotetext{
${ }_{3}^{3}$ Undang-Undang Sistem Peradilan Pidana Anak Nomor 11 Tahun 2012 Bab I Ketentuan Umum angka 7

4 Undang-Undang Sistem Peradilan Pidana Anak Nomor 11 Tahun 2012 Bab I Ketentuan Umum angka 6
} 
pidana tersebut dapat diselesaikan dengan baik dengan tercapainya persetujuan dan kesepakatan diantara para pihak 5 .

Didalam prosesnya, diversi melibatkan peran masyarakat untuk mewujudkan keadilan restoratif. Hal ini telah diakomodir dalam beberapa pasal undang-undang Nomor 11 tahun 2012 tentang SPPA ${ }^{6}$ yaitu:

1. Proses Diversi dilakukan melalui musyawarah dengan melibatkan anak dan orang tua/walinya, korban dan/atau orang tua/walinya, pembimbing kemasyarakatan, dan pekerja sosial profesional berdasarkan pendekatan Keadilan Restoratif.

2. Dalam hal diperlukan, musyawarah sebagaimana dimaksud pada ayat (1) dapat melibatkan tenaga kesejahteraan sosial, dan/atau masyarakat

Dengan demikian peran serta masyarakat dalam proses diversi untuk mewujudkan keadilan restoratif sangat strategis, untuk menghindarkan anak dari tindak pidana dan mendukung terciptanya Cirebon sebagai kota layak anak, juga sebagai upaya preventif terhadap pengulangan tindak pidana. Namun indikasi dilapangan menunjukkan masih marak terjadi tindak pidana anak sehingga muncul pertanyaan antara lain 1) bagaimana peran masyarakat dalam proses diversi untuk mewujudkan keadilan restoratif 2) permasalahan peran masyarakat dalam proses diversi untuk mewujudkan keadilan restoratif.

Pentingnya melihat letak perbedaan penelitian ini dengan penelitian-penelitian terdahulu, maka penulis mencantumkan beberapa penelitian terdahulu yang relevan. Pertama, penelitian dengan judul “Peran Tokoh Masyarakat Dalam Proses Diversi yang Diterapkan terhadap Anak

5 Hermanto Sitohang, 'Restorative Justice (Pengertian, Prinsip, Dan Keberlakuannya Dalam Sistem Hukum Pidana Indonesia)', 2013, p. http://edwinnotaris.blogspot.com/2013/09/restorati.

6 Undang-Undang Sistem Peradilan Pidana Anak Nomor 11 Tahun 2012 Pasal 8 Ayat (1) dan (2) 
yang Berkonflik dengan Hukum Pidana"7. Penelitian sejenis lainnya adalah "Peran Masyarakat dan Penyelesaian Perkara Pidana Anak Melalui Peradilan Restoratif". Selain itu juga "Model Peradilan Restoratif dalam Sistem Peradilan Pidana Anak (Kajian tentang Praktik Mediasi Pelaku dan Korban dalam Poses Peadilan Pidana Anak di Wilayah Hukum Bapas Purwokerto)" ${ }^{\prime \prime}$.

Studi ini melihat lebih dalam peran masyarakat dalam proses diversi tindak pidana kekerasan dalam upaya mewujudkan keadilan restoratif. Objek kajian penelitian ini adalah perkara tindak pidana anak yang diselesaikan melalui proses diversi di Kota Cirebon.

Informan penelitian diperoleh menggunakan purposive sampling dengan menggunakan metode snowball sebagai cara pemilihan informan sesuai dengan kedalaman pengetahuan informan terkait informasi yang akan dicari. Sumber data diambil menggunakan wawancara mendalam, observasi dan studi dokumentasi ${ }^{10}$. Penelitian ini tidak menentukan besaran jumlah informan akan tetapi yang diajdikan informan adalah para pihak yang relevan seperti ahli hukum pidana yakni Profesor Ibnu Artadi Dekan Fakultas Hukum Universitas Gunungjati Cirebon, Unsur Kepolisian Resor Ciko, hakim anak, jaksa penuntut umum anak, pekerja sosial profesional dari Dinas Sosial Pemberdayaan Perempuan dan Perlidungan Anak (DSPPPA) Kota Cirebon, tokoh masyarakat serta Pembimbing Kemasyarakatan (PK) dari Balai Pemasyarakatan (Bapas) Kelas I Cirebon.

\footnotetext{
7 The Deanita Wibowo, 'Peran Tokoh Masyarakat Dalam Proses Diversi Yang Diterapkan Terhadap Anak Yang Berkonflik Dengan Hukum Pidana' (Unika Soegijapranata Semarang, 2018).

8 Dyah Indria Kusuma Wardhani, Peran Masyarakat Dalam Penyelesaian Perkara Pidana Anak Melalui Peradilan Restoratif (Surakarta, 2016).

9 Angkasa, Saryono Hanadi, and Muhammad Budi Setiyadi, 'Model Peradilan Restoratif Dalam Sistem Peradilan Anak (Kajian Tentang Praktik Mediasi Pelaku Dan Korban Dalam Proses Peradilan Anak Di Wilayah Hukum Balai Pemasyarakatan Purwokerto)', Jurnal Dinamika Hukum, 9.3 (2009), p. 186.

${ }^{10}$ Burhan Bungin, Analisis Data Kualitatif (Jakarta: Raja Grafindo Persada, 2005).
} 


\section{HASIL DAN PEMBAHASAN}

\section{Peran Serta Masyarakat}

Dalam sistem peradilan anak, utamanya dalam penyelesaian melalui proses diversi, masyarakat memiliki peran yang sangat menentukan tingkat keberhasilannya, masyarakat yang dimaksud dalam undang undang antara lain tokoh agama, guru, dan tokoh masyarakat ${ }^{11}$. Peran masyarakat dirinci lebih detail pada Pasal 93 di mana masyarakat dapat berperan serta dalam perlindungan Anak mulai dari pencegahan sampai dengan reintegrasi sosial Anak dengan cara:

1. Menyampaikan laporan terjadinya pelanggaran hak anak kepada pihak yang berwenang;

2. Mengajukan usulan mengenai perumusan dan kebijakan yang berkaitan dengan anak;

3. Melakukan penelitian dan pendidikan mengenai anak;

4. Berpartisipasi dalam penyelesaian perkara anak melalui diversi dan pendekatan keadilan restoratif;

5. Berkontribusi dalam rehabilitasi dan reintegrasi sosial anak, anak korban dan/atau anak saksi melalui organisasi kemasyarakatan;

6. Melakukan pemantauan terhadap kinerja aparat penegak hukum dalam penanganan perkara anak ${ }^{12}$

Pembimbing Kemasyarakatan Bapas Kelas I Cirebon dalam wawancara mengatakan:

"Fasilitator beberapa kali tidak dapat menghadirkan masyarakat, baik guru, tokoh agama, tokoh pemuda atau aparat pemerintah desa karena beberapa hal, misalnya fasilitator tidak sempat mengundang, tidak mengetahui untuk diundang, sudah diundang namun tidak hadir atau menganggap

\footnotetext{
${ }^{11}$ Undang-Undang Sistem Peradilan Pidana Anak Nomor 11 Tahun 2012 Penjelasan Pasal 8 Ayat (2)

12 Undang-Undang Sistem Peradilan Pidana Anak Nomor 11 Tahun 2012 Bab IX Pasal 83
} 
tidak perlu untuk di hadirkan karena dianggap permasalahan telah didamaikan."13

Begitu juga Penyidik Anak yang menyampaikan hal yang sama, bahwa pada intinya mereka telah menyampaikaan undangan baik lisan maupun tertulis kepada masyarakat untuk menghadiri proses Diversi. Pembaharuan Undang-Undang Nomor 3 Tahun 1997 ke Undang-Undang Nomor 11 Tahun 2012 adalah karena regulasi sebelumnya secara komprehensif belum memberikan perlindungan kepada anak yang berhadapan dengan hukum dengan baik. Dalam Undang-undang ini muncul paradigma Keadilan Restpratif,.

Pekerja Sosial Profesional Siti Fatimah, A.KS dari Dinas Sosial Pemberdayaan Perempuan dan Perlindungan Anak (DSPPPA) Kota Ciebon memberikan penekanan pentingnya peran masyarakat, menurutnya ketika sebuah proses hukum telah selesai mendapatkan keputusan yang final, antara pelaku dan korban akan kembali kemasyarakat, disinilah pihak terkait yaitu Bapas, Dinas Sosial dan masyarakat menjadi penentu perubahan sikap dari anak pelaku. Tidak hanya itu, masyarakat juga memiliki peran mendukung mengembalikan resosialisasi antar kedua belah pihak ditengah kehidupan masyarakat, menghindarkan stigma negatif sehingga Anak bisa tumbuh kembang dengan baik ${ }^{14}$.

Salah satu tokoh masyarakat yang pernah mengikuti proses Diversi menyampaikan bahwa sangat mendukung upaya diversi dan peran yang dilakukan dalam masyarakat adalah. Memberikan penjelasan kepada masyarakat setempat bawah anak usia remaja sering terpengaruh oleh lingkungan atau pergaulan yg tidak baik pada nya usia tersebut masih labil atau blm menemukan jati diri nya sebagai orang tua atau tokoh masyarakat

13 Wawancara dengan Bing Kodir Pembimbng Kemasyarakatan Bapas Kelas I Cirebon, pada tanggal 13 Mei 2020

14 Wawancara dengan Peksos Profesional, Siti Fatimah A.KS dari Dinas Sosial Pemberdayaan Perempuan dan Perlindungan Anak (DSPPPA) Kota Ciebon, pada tanggal 9 April 2020 
harus selalu menasehati dan mengingatkan untuk lebih baik dan memberikan kesempatan anak itu agar menjadi orang yg lebih baik ${ }^{15}$.

Disisi lain beliu juga mengetahui sedikit tentang Diversi ini karena dilibatkan dalam prosesnya dan berharap agar masyarakat diberikan pemahaman tentang penanganan hukum terhadap Anak yang berhadapan dengan hukum termasuk didalamnya Diversi sehingga dapat berperan dalam menciptakan keadilan bagi masyarakat.

\section{Diversi}

Diversi merupakan alat baru yang ditawarkan di peradilan anak dengan mengedepankan kesejahteraan dan keseimbangan yang juga dirasa mampu menciptakan efisiensi peradilan di Indonesia. Diversi adalah pengalihan dari proses pengadilan pidana ke luar proses formal untuk diselesaikan secara musyawarah. Di dalam UU RI Nomor 11 Tahun 2012 tentang SPPA, diversi, diatur lebih detail dalam beberapa pasalnya.

1. Pasal 6,

Diversi bertujuan:

a. mencapai perdamaian antara korban dan anak;

b. menyelesaikan perkara anak di luar proses peradilan;

c. menghindarkan anak dari perampasan kemerdekaan;

d. mendorong masyarakat untuk berpartisipasi; dan

e. menanamkan rasa tanggung jawab kepada anak

Pasal ini memiliki makna perlindungan hak sekaligus pembinaan terhadap anak pelaku dimana anak dihindarkan dari beban psykologis dari proses peradilan di satu sisi rasa tanggung jawab anak terhadap tindakan yang telah dilakukan.Masyarakat juga diberikan peran dalam proses Diversi maupun dalam tahap post Diversi dalam bentuk pembimbingan dan pengawasasan.

Kendalaa dalam tahap ini, seorang Anak Pelaku atau orang tua, bila perkara diselesaikan dengan Diversi, diartikan perkara selesai tanpa

\footnotetext{
${ }^{15}$ Wawancara dengan tokoh masyarakat, Sabihi, pada tanggal 9 April 2020
} 
konsekwensi hukum. Padahal dalam kesepakatan Diversi banyak alternatif yang bisa diambil untuk mewujudkan Keadilan Restoratif. Sedangkan syarat Diversi sesuai dengan Pasal 7 adalah :

1) Pada tingkat penyidikan, penuntutan, dan pemeriksaan perkara Anak di pengadilan negeri wajib diupayakan Diversi.

2) Diversi sebagaimana dimaksud pada ayat (1) dilaksanakan dalam hal tindak pidana yang dilakukan

a. Diancam dengan pidana penjara di bawah 7 (tujuh) tahun; dan

b. Bukan merupakan pengulangan tindak pidana

Di dalam pasal ini khususnya pada ayat (2) masih banyak penafsiran yang berbeda dari Aparat Penegak Hukum (APH), ada yang beranggapan point (a) diancam dengan pidana penjara di bawah 7 (tujuh) tahun, termasuk didalamnya tindak pidana yang ancamannya tepat 7 (tujuh) tahun dengan catatan pihak korban menyetujui penyelesaian melalui proses Diversi.

Pada ayat 2 huruf (b), membawa pengaruh posistif pada $\mathrm{ABH}$, dimana mereka harus merubah perilakunya .karena jika klien mengulangi tindak pidana, tidak akan ada kesempatan untuk menyelesaikan melalui Diversi ${ }^{16}$

Berbagai alternatif kesepakatan dalam sebuah Diversi tergantung dari latar belakang $\mathrm{ABH}$ dan situasional kasus itu sendiri, berkaitan dengan bentuk kesepakatan Diversi diatur dalam pasal 11 antara lain:

a. Perdamaian dengan atau tanpa ganti kerugian;

b. Penyerahan kembali kepada orang tua/Wali;

c. Keikutsertaan dalam pendidikan atau pelatihan di lembaga pendidikan atau LPKS paling lama 3 (tiga) bulan; atau

d. Pelayanan masyarakat ${ }^{17}$

\footnotetext{
${ }_{16}$ Undang-Undang Sistem Peradilan Pidana Anak Nomor 11 Tahun 2012 Pasal 6 dan 7

17 Undang-Undang Sistem Peradilan Pidana Anak Nomor 11 Tahun 2012 pasal 11
} 
Prof Dr. Ibnu Artadi Dekan Fakultas Hukum Universitas Gunungjati Cirebon, menyampaikan bahwa Diversi bukan Diskresi, banyak alternatif yang bisa dipilih untuk kepentingan terbaik bagi klien. terkadang pemahaman dari masyarakat bahkan $\mathrm{APH}$, diversi identik dengan kembali orang tua dan penggantian kerugian. Padahal dua alternative tadi dalam kondisi tertentu kurang memberikan pendidikan dan kurang menumbuhkan tanggung jawab anak karena kedua pilihan tadi orang tua yang melaksanakan. Harus ada stressing sehingga anak menyadari akan kesalahan dan tidak mengulangi di kemudian hari ${ }^{18}$.

Sementara itu Penyidik Anak dari Polres Ciko menyampaikan kendala dalam proses upaya Diversi yaitu menyatukan pemikiran antara pihak Korban dan pihak Anak yang sedang berhadapan dengan hukum agar tercapainya kesepakatan. Menerangkan pemahaman apa itu Diversi kepada pihak korban serta keluarganya dan kepada anak yg berhadapan dengan hukum maupun keluarganya ${ }^{19}$.

Di dalam Peraturan Pemerintah Nomor 65 tahun 2015 tentang Pedoman Pelaksanaan Diversi dan Penanganan Anak yang belum berumur 12 tahun (Pasal 11):

1) Selama proses Diversi, anak ditempatkan bersama orang tua/wali.

2) Dalam hal Anak tidak memiliki orang tua/wali maka Anak ditempatkan di

3) LPKS.

4) Dengan mempertimbangkan kepentingan terbaik bagi anak, anak yang

5) memiliki orang tua dapat ditempatkan di LPKS.

6) Ketentuan lebih lanjut mengenai tata cara penempatan anak selama proses Diversi diatur dengan Peraturan Menteri yang

\footnotetext{
18 Wawancara dengan Prof Dr. Ibnu Artadi Dekan Fakultas Hukum Universitas Gunungjati Cirebon

${ }^{19}$ Wawancara dengan Dwi Kanit PPA Polres Ciko, pada tanggal 14 Mei 2020
} 
menyelenggarakan urusan pemerintahan di bidang hukum dan hak asasi manusia ${ }^{20}$

Ada beberapa kendala untuk mengimplementasikan pasal ini, yang pertama, dalam kasus tertentu penyidik merasa takut bila anak kabur ketika tidak ditahan, yang kedua di Cirebon belum terdapat LPKS.

\section{Keadilan Restoratif}

Sistem Peradilan Pidana Anak adalah keseluruhan proses penyelesaian perkara Anak yang berhadapan dengan hukum, mulai tahap penyelidikan sampai dengan tahap pembimbingan setelah menjalani pidana, sedangkan Anak yang Berhadapan dengan Hukum $(\mathrm{ABH})$ adalah. anak yang berkonflik dengan hukum, anak yang menjadi korban tindak pidana, dan anak yang menjadi saksi tindak pidana ${ }^{21}$. Sedangkan menurut Undang-undang Perlindungan Anak.Dalam Pasal 1 angka 1 UndangUndang No. 23 Tahun 2002 tentang Perlindungan Anak mendefinisikan anak sebagai berikut, Anak adalah seseorang yang belum berusia 18 tahun, termasuk anak yang masih dalam kandungan ${ }^{22}$.

Konsep keadilan restoratif atau keadilan pemulihan (restorative justice) merupakan suatu model pendekatan baru dalam upaya penyelesaian perkara pidana. Keadilan restoratif atau keadilan pemulihan (restorative justice) lebih menitikberatkan pada adanya partisipasi langsung dari pelaku, korban dan masyarakat dalam proses penyelesaian perkara pidana. Oleh karena itu, pendekatan ini populer disebut juga dengan non state justice system, di mana peran Negara dalam penyelesaian perkara pidana menjadi kecil atau bahkan tidak ada sama sekali. Namun demikian, kehadiran pendekatan atau konsep keadilan restoratif atau keadilan pemulihan (restorative justice) banyak diwarnai berbagai pertanyaan baik secara teoritis maupun secara praktis ${ }^{23}$.

\footnotetext{
20 Peraturan Pemerintah Nomor 65 tahun 2015 pasal 11

${ }^{21}$ Undang-Undang Sistem Peradilan Pidana Anak Nomor 11 Tahun 2012 Ketentuan Umum Bab I angka 4

22 Undang-Undang Perlindungan Anak Nomor 23Tahun 2002 Ketentuan Umum angka 1

23 'Restorative Justice', 2009, p. http://evacentre.blogspot.com/2009/11/restorative-.
} 
Bayu Razam, Hakim Anak memberikan keterangan tentang keterlibatan masyarakat dalam upaya Diversi untuk menujudkan keadilan Restoratif sebagai berikut:

"Masyarakat dapat dilibatkan dalam proses diversi di PN apabila Fasilitator Diversi menganggap dibutuhkan peran masyarakat,terutama Tokoh Masyarakat dan Tokoh Agama,seingat Saya pernah mengundang Tokoh Masyarakat dalam proses diversi,saat itu Pak RT tempat tinggal Anak,jadi Pak RT dapat menceritakan tentang kehidupan sehari-hari keluarga Anak dan perilaku Anak.Hal ini tentunya akan membantu fasilitator dalam mencari solusi/penanganan terbaik untuk Anak.Mengenai efektifitasnya,dalam proses diversi,tentunya akan menambah opsi dan pengetahuan bagi fasilitator diversi"24.

Bayu menafsirkan kata 'dapat' yang artinya 'tidak harus' walaupun kata tersebut bisa diartikan 'lebih baik' masyarakat dilibatkan dan harus mendapat persetujuan para pihak. Dalam hal mewujudkan Keadilan Restoratif dan mengembalikan kondisi inetraksi sosial Anak dalam keluarga dan dengan masyarakat atau antara keluarga Anak Pelaku dengan keluarga Korban didalam masyarakat, tentunya masyarakat yang dilibatkan dalam hal proses upaya Diversi bersama Pekerja Sosial Profesional dan Pembimbing Kemasyarakatan dari Bapas Cirebon, berupaya melakukan hal terbaik untuk kepentingan Anak Pelaku, Korban dan Saksi serta masyarakat secara keseluruhan.

Menurut Sabihi, akan sulit menciptakan kondisi yang dirasa adil oleh kedua belah pihak dan masyarakat tanpa dukungan dan bantuan para pihak seperti penyidik, Pekerja Sosial, petugas Bapas dan aparat pemerintah desa ${ }^{25}$. Sementara tokoh pemuda Jaka Permana memberikan usulan solusi untuk menekan tawuran remaja di Cirebon dengan menindak tegas para pelaku termasuk yang ikut-ikutan/simpatisan, pemerintah, TNI / POLRI memberikan pembinaan kesetiap sekolah SMP/SMA, penyuluhan dampak negatif tawuran/tindakan yg merugikan orang banyak secara rutin, aktifkan karang taruna tiap kelurahan agar memantau kegiatan anak muda, Aktifkan mantan" geng untuk memberikan sosialisasi karena mereka lebih paham keadaan jalanan / pemikiran anak muda karena mereka

\footnotetext{
24 Wawancara dengan Bayu Razam Hakim Anak, pada tanggal 14 Mei 2020

${ }^{25}$ Wawancara dengan Sabihi Tokoh Masyarakat, pada tanggal 13 Mei 2020
} 
pernah merasakan, Ajak komunikasi, tukar pendapat, berikan wadah dan tempat untuk bermusyawarah ${ }^{26}$.

Panglima XTC Kota Cirebon tersebut berharap semua lapisan masyarakat tidak hanya dalam ranah Diversi, namun dalam upaya pencegahan saling membahu dan mendukung guna menciptakan Kota Cirebon yang ramah anak. Bagi para pelaku yang ikut dalam rombongan juga diharapkan mendapatkan proses hukum sehingga mendapatkan pembinaan yang baik.

Pembimbing Kemasyarakatan dari Bapas Kelas I Cirebon mengatakan adalah salah satu peran masyarakat yang sebenarnya sangat urgen dalam Diversi atauoun penanganan ABH yaitu membuat Lembaga Penyelenggaraan Kesejahteraan Sosial (LPKS) berbasis masyarakat. Karena lembaga tersebut digunakan dalam tahapan praadjudikasi, adjudikasi dan post adjudikasi, tanpa harus penyedian fasilitas dari pemerinah. Hal ini bisa dilakukan dengan cara optimalisasi lembaga pendidikan dan keagamaan dengan menerima rehabilitasi sosial $\mathrm{ABH}$.

Kondisi saat ini ketika Vonis hakim maupun hasil kesepakatan Diversi merujuk ke LPKS, biasanya ke Panti Rehabilitasi Sosial Anak Berhadapan dengan Hukum (PSRABH) yang ada di Bogor. Menjauhkan peluang pertemuan anak dengan keluarganya. Beberapa perspektif mengapa peran masyarakat dianggap penting dalam Diversi terhadap tindak kekerasan Remaja dalam upaya mewujudkan keadilan restoratif di Kota Cirebon adalah :

1. Perspektif Yuridis

a. Didalam pasal 8 dinyatakan bahwa Masyarakat/tokoh masyarakat dapat berperan dalam proses Diversi., walaupun dalam reksionalnya dikatan "Dapat" namun dalam implementasikan sangat diperlukan

b. Banyaknya pilihan kesepakatan diversi, yang mau tidak mau dalam pelaksanaannya harus melibatkan masyarakat.

2. Perspektif Sosiologis ${ }^{26}$ Wawancara dengan Jaka Permana Panglima XTC Kota Cirebon, pada tanggal 14
Mei 2020 
Diversi yang menggunakan pendekatan Keadilan Restoratif/pemulihan dalam kehiduoan sosial, tentunya antara Anak Pelaku dengan korban dan keluarga serta masyarakat memerlukan mediator, pembimbung dan pengawas, dalam hal ini tidak bisa megandalkan hanya instansi terkait seperti Bapas dan Peksos tetapi keterlibatan masyarakat akan lebih efektif untuk mewujudkan keadilan restoratif tersebut.

3. Tinjauan Psikologis

$\mathrm{ABH}$ dan keluarga cenderung mengalami trauma dan stigma negatif dalam kehidupan masyarakat, untuk itu peran masyarakat dalam proses diversi sangat strategis untuk mengikis trauma dan stigma negatif tersebut sehingga psykososial $\mathrm{ABH}$ dan keluarga dan kembali pulih.

\section{SIMPULAN}

Masyarakat belum selalu dapat dihadirkan dalam proses Diversi dengan beberapa alasan, tidak diundang, diundang tidak hadir karena tidak paham atau karena kesibukan. Keterlibatakn masyarakat sangat strategis dalam upaya diversi maupun dalam pelaksanaan hasil kesepakatan Diversi guna mewujudkan keadilan Restoratif di Kota Cirebon. Masyarakat dapat berperan dalam hal Rehabilitasi sosial $\mathrm{ABH}$ dengan mengoptimalkan lembaga Sosial yang berbasis agama maupun pendidikan. Angka tindak pidana kekerasan antar kelompok remaja di Kota Cirebon cukup tinggi, Diversi sebagai salah satu terobosan baru dalam SPPA belum dioptimalkan khususnya bagi pelaku yang hanya ikut-ikutan saja. Adapun saran yaitu Fasilitator dapat mengupayakan keterlibatan masyarakat dalam proses Diversi walaupun dalam redaksional peraturannya adalah "dapat" namun dalam kenyataannya masyarakat/tokoh masyarakat memiliki peran startegis baik dalam upaya Diveri maupun pelaksanaan hasil kesepakatan Diversi. Perlunya pemahaman kepada masyarakat tentang mekanisme penanganan $\mathrm{ABH}$ termasuk didalamnya adalah Diversi, oleh pihak yang berkompeten (Penyidik, Peksos Profesional JPU Anak, Hakim Anak dan Pembimbing Kemasyarakatan). Perlu diskusi mendalam antar pihak yang terkait dalam 
SPPA dengan Pemda Kota Cirebon serta tokoh masyarakat guna mewujudkan LPKS dan menangani maraknya tindak pidana kekekrasan remaja di Kota Cirebon. Demi kepentingan terbaik bagi anak, dipandang perlu Optimalisasi Diversi dalam setiap perkara $\mathrm{ABH}$ yang terbukti melanggar Undang-Undang dengan ancaman dibawah 07 (tujuh) tahun, sehingga anak mendapat pembimbingan yang lebih komprehensip dari berbagai institusi. 


\section{DAFTAR PUSTAKA}

Angkasa, Saryono Hanadi, and Muhammad Budi Setiyadi, 'Model Peradilan Restoratif Dalam Sistem Peradilan Anak (Kajian Tentang Praktik Mediasi Pelaku Dan Korban Dalam Proses Peradilan Anak Di Wilayah Hukum Balai Pemasyarakatan Purwokerto)', Jurnal Dinamika Hukum, 9.3 (2009), 186

Bungin, Burhan, Analisis Data Kualitatif (Jakarta: Raja Grafindo Persada, 2005)

'Restorative

Justice', 2009, p.

http://evacentre.blogspot.com/2009/11/restorative-

Sitohang, Hermanto, 'Restorative Justice (Pengertian, Prinsip, Dan

Keberlakuannya Dalam Sistem Hukum Pidana Indonesia)', 2013, p. http://edwinnotaris.blogspot.com/2013/09/restorati

Sumber Data Balai Pemasyarakatan (Bapas) Pas Kelas 1 Cirebon (Cirebon, 2019)

Wardhani, Dyah Indria Kusuma, Peran Masyarakat Dalam Penyelesaian

Perkara Pidana Anak Melalui Peradilan Restoratif (Surakarta, 2016)

Wibowo, The Deanita, 'Peran Tokoh Masyarakat Dalam Proses Diversi

Yang Diterapkan Terhadap Anak Yang Berkonflik Dengan Hukum

Pidana' (Unika Soegijapranata Semarang, 2018)

Peraturan Pemerintah Nomor 65 tahun 2015 pasal 11

Undang-Undang Sistem Peradilan Pidana Anak Nomor 11 Tahun 2012 Bab I Ketentuan Umum angka 6

Undang-Undang Sistem Peradilan Pidana Anak Nomor 11 Tahun 2012 Bab I Ketentuan Umum angka 7

Undang-Undang Sistem Peradilan Pidana Anak Nomor 11 Tahun 2012 Pasal 8 Ayat (1) dan (2) 
Undang-Undang Sistem Peradilan Pidana Anak Nomor 11 Tahun 2012 Bab IX Pasal 83

Undang-Undang Sistem Peradilan Pidana Anak Nomor 11 Tahun 2012 Ketentuan Umum Bab I angka 4

Wawancara dengan Bayu Razam Hakim Anak, pada tanggal 14 Mei 2020

Wawancara dengan Bing Kodir Pembimbng Kemasyarakatan Bapas Kelas I

Cirebon, pada tanggal 13 Mei 2020

Wawancara dengan Dwi Kanit PPA Polres Ciko, pada tanggal 14 Mei 2020

Wawancara dengan Jaka Permana Panglima XTC Kota Cirebon, pada tanggal 10 April 2020

Wawancara dengan Sabihi tokoh masyarakat, pada tanggal 9 April 2020

Wawancara dengan Prof Dr. Ibnu Artadi Dekan Fakultas Hukum Universitas Gunungjati Cirebon

Wawancara dengan Siti Fatimah A.KS Peksos Profesional dari Dinas Sosial Pemberdayaan Perempuan dan Perlindungan Anak (DSPPPA) Kota Ciebon, pada tanggal 9 April 2020 